\title{
Digestive enzyme activity in the guts of Epilachna chrysomelina (Fabricius) (Coleoptera: Coccinellidae) during post-embryonic development
}

\author{
Akinkunmi Olukemi Yetunde ${ }^{1 *}$, Pitan Olufemi Richard ${ }^{2}$, Ademolu Kehinde \\ Olutoyin $^{3}$ and Osipitan Adebola Adedoyin ${ }^{2}$
}

\section{ABSTRACT}

The gut regions of Epilachna chrysomelina are endowed with multiple enzymes that aid digestion of host plant tissues. Digestive enzymes present in the gut regions of $E$. chrysomelina during various developmental stages were studied in the laboratory to determine the most destructive life stage of the beetle for proper management measures. Cellulase, a-glucosidase, amylase, lipase and proteinase activities were observed in the guts. The mid-gut recorded significantly higher $(p<0.05)$ enzymes than other gut sections except amylase where higher activity was observed in the foregut. Lipase (38.24Abs per min), a-glucosidase (25.65Abs per min) and proteinase (28.70Abs per min) activities were significantly higher in the immature stages while cellulase (19.46Abs per min) and amylase activities (16.62Abs per min) were higher in the adult stage. The $4^{\text {th }}$ instar larval and the adult stages recorded higher enzyme activities and thus can be regarded as the most destructive stages of development.

Keywords: Gut enzyme, Epilachna chrysomelina, post-embryonic, development, digestion

\section{INTRODUCTION}

The African melon lady beetle Epilachna chrysomelina is a destructive pest which inflicts major economic damage on cucurbits and solanaceae crops (Pitan and Filani 2013). The adults and larvae feed on leaves and fruits of the host plant and cause damage which is characterized by the presence of skeletonization of the leaves as well as grooves, scarification and patches on fruits which adversely

'National Horticultural Research Institute, PMB 5432 Jericho, Idi-Ishin Ibadan, Nigeria

${ }^{2}$ Department of Crop Protection, Federal University of Agriculture, Abeokuta, Nigeria

${ }^{3}$ Department of Pure and Applied Zoology, Federal University of Agriculture, Abeokuta, Nigeria

*Corresponding Author. Address: National Horticultural Research Institute, PMB 5432 Jericho, Idi-Ishin Ibadan, Nigeria; Email:akinkunmikemi1@gmail.com

(C) Visayas State University, Baybay City, Leyte, Philippines 
affects both quality and quantity of crop output (Pitan and Esan 2013, Katoh et al 2014). The beetle, as reported by Vishav et al (2017) and Akinkunmi (2020) undergoes complete metamorphosis (holometabolous) with distinct egg, four larval instars, pupa and adult stages. The third and fourth instar larvae were reported to be more destructive and voracious (Hossein et al 2009, Akinkunmi 2020). Infestation primarily begins from just after hatching of the egg mass (Murata et al 1994). The adults in addition to leaf-scrapping eat up chunks of cucumber tissues and make grooves on them rendering the fruit unsightly and unmarketable (Pitan and Filani 2013). Digestion of host tissues takes place in the digestive tract which is a continuous tube running from the mouth to the anus of the beetle and is divided into the foregut, midgut and hindgut (Chapman 1990). Insects are endowed with multiple enzymes which aid digestion in the gut regions (Adedire et al 1999, Ademolu et al 2013). Earlier studies identified the adults and larval stages of the beetle as the most damaging stages (Pitan and Esan 2013, Katoh et al 2014). However, little or no empirical data had been documented on the digestive enzyme activities in the guts during post-embryonic development. This information will help in the understanding of the digestion process and utilization of nutrients during this period. This study therefore aimed at identifying the enzymes present in the guts of E. chrysomelina during post-embryonic development and to identify the gut region with the highest digestive enzyme activity.

\section{MATERIALS AND METHODS}

\section{Insect Collection and Rearing}

The experiment was carried out at the Department of Pure and Applied Zoology, Federal University of Agriculture, Abeokuta, Ogun State, Nigeria. The initial stock of adult $E$. chrysomelina was obtained from field populations infesting cucumber plants. The beetles were collected and later released into wooden cages $(65 \mathrm{~cm} \times 65 \mathrm{~cm} \times 70 \mathrm{~cm})$ where cucumber was planted. The adult beetles were removed 10 days after introduction into the cages after which time they should have mated and laid eggs. Insect culture was maintained under ambient temperature $25^{\circ} \mathrm{C}-28^{\circ} \mathrm{C}$ and relative humidity $75-90 \%$. Emerged larvae and adults were used for the study.

\section{Insect Preparation for the Study}

Twenty (20) beetles per developmental stage were collected from the culture and asphyxiated in a deep freezer at $-4^{\circ} \mathrm{C}$ for $30 \mathrm{~min}$, after which their guts were carefully dissected out. The alimentary canal of each beetle was partitioned into foregut, midgut and hindgut. This was later homogenized separately in $50 \mathrm{~mL} 0.05 \mathrm{M}$ $\mathrm{KCl}$ and centrifuged at $500 \mathrm{rpm}$ for $30 \mathrm{~min}$ at $5^{\circ} \mathrm{C}$. The enzyme extract $(50 \mathrm{~mL})$ produced from each gut was decanted in a centrifuge tube and stored in the freezer at $-4^{\circ} \mathrm{C}$ until use.

\section{Determination of Enzyme Activity in the Guts}

Enzyme activities were determined following the method described by Adedire and Balogun (1995) and Ademolu and Idowu (2011). All the enzyme assays were 
carried out in triplicate according to the method of Ademolu and Idowu (2011).

\section{Determination of Cellulase Activity (Abs/min)}

A $0.5 \mathrm{~mL}$ sample of the initial enzyme extract was pipetted into a $25 \mathrm{~mL}$ test-tube into which $0.5 \mathrm{~mL}$ of $1 \%$ carboxymethyl cellulose solution had been added. The testtube was incubated for $30 \mathrm{~min}$ at $50^{\circ} \mathrm{C}$, after which $1 \mathrm{~mL}$ of DNSA (dinitrosalicylic acid) reagent was added and the mixture heated to $100^{\circ} \mathrm{C}$ in a water bath for $5 \mathrm{~min}$. The mixture was cooled to room temperature after which $10 \mathrm{~mL}$ distilled water was added. Cellulose and glucose standard solutions were prepared and treated the same way. The absorbance of the treated sample extract as well as the cellulose standard were measured after $1 \mathrm{~min}$ using a 600 spectrophotometer at $540 \mathrm{~nm}$ wavelength.

\section{Determination of a-glucosidase Activity (Abs/min)}

A one molar solution of para-hydroxyl benzoic acid was mixed with $0.5 \mathrm{~mL}$ of the enzyme extract after which $5 \mathrm{~mL}$ of $0.1 \mathrm{M}$ sodium phosphate buffer at $\mathrm{pH} 5.5$ and $1 \mathrm{~mL}$ of distilled water was added. Later, DNSA (dinitrosalicylic acid) reagent $(1 \mathrm{~mL})$ was added to the mixture and the mixture heated to $100^{\circ} \mathrm{C}$ in a water bath for $5 \mathrm{~min}$. The mixture was rapidly cooled to room temperature after which $10 \mathrm{~mL}$ distilled water was added. A standard solution of glucosidase enzyme was also prepared and treated the same way. The absorbances of the treated sample extract as well as the glucosidase standard were measured after $1 \mathrm{~min}$ using a Cecil 600 spectrophotometer at $530 \mathrm{~nm}$ wavelength.

\section{Determination of Amylase Activity (Abs/min)}

A $2 \mathrm{~mL}$ sample of the enzyme extracted was mixed to $1 \mathrm{M}$ potassium hydrogen phosphate buffer (pH6.9) and $1 \mathrm{~mL}$ of a $1 \%$ starch solution. The mixture was incubated for $1 \mathrm{~h}$ at $40^{\circ} \mathrm{C}$. DNSA reagent $(8 \mathrm{~mL})$ was later added and the mixture boiled in a water bath for $5 \mathrm{~min}$ which was later cooled in a cold water bath. The mixture was then diluted with $18 \mathrm{~mL}$ distilled water. The absorbance of the sample was read on an SP 6250 spectrophotometer at 540 nm wavelength and compared with that of the standard solution.

\section{Determination of Lipase Activity (Abs/min)}

A $7.5 \mathrm{~mL}$ sample of the enzyme extracted and $0.2 \mathrm{M}$ sodium acetate-acetic acid ( $\mathrm{pH} 5)$ was added to the reaction medium containing $0.4 \mathrm{~g}$ of sodium taurocholate, $1 \mathrm{~mL}$ of $0.1 \mathrm{M} \mathrm{CaCl}_{2}$ and $6 \mathrm{~mL}$ of sodium acetate mixture. The mixture was incubated at $35^{\circ} \mathrm{C}$ for $1 \mathrm{~h}$ and the reaction was then stopped by adding $40 \mathrm{~mL}$ absolute methanol. A standard lipase solution was also prepared using distilled water. The absorbance of the sample and standard was read at wavelength $415 \mathrm{~nm}$ on a Cecil 600 spectrophotometer.

\section{Determination of Proteinase Activity (Abs/min)}

A $5 \mathrm{~mL}$ sample of the enzyme extracted and $0.1 \mathrm{M}$ sodium hydrogen phosphate ( $\mathrm{pH} 6.9$ ) were added to $10 \mathrm{~mL}$ of $2 \%$ casein solution and incubated at $35^{\circ} \mathrm{C}$ for $30 \mathrm{~min}$. 
The reaction was terminated by adding $10 \mathrm{~mL}$ of $10 \%$ trichloroacetic acid solution and then filtered through a Whatman No 1 filter paper. A standard proteinase solution was also prepared and the absorbance of the samples was read and compared. Proteinase activity was measured as the amount of proteinase capable of catalyzing absorbance Change of 0.01 in 60 s at a wavelength of $275 \mathrm{~nm}$.

\section{Data Analysis}

The data collected in the study were subjected to one-way analysis of variance (ANOVA) and significant means were separated using Student-Newman-Keuls (SNK) test.

\section{RESULTS AND DISCUSSION}

E.chrysomelina possesses a well-developed digestive system containing digestive enzymes with which the beetle digests the different host plants that it feeds on. Cellulase, a-glucosidase, amylase, lipase and proteinase were the enzymes present in the gut region of both the immature and adult stages of the beetle in this study. Earlier studies by Adedire and Balogun (1995) as well as Ademolu and Idowu (2011) showed the presence of the same enzymes in kolanut weevil, Sophrorhinus insperatus and Zonocerus variegatus respectively with which these insects hydrolyse or digest consumed food substances. Secretion of enzymes in the gut region is determined by the kind of food or nutrients provided to the insect during the rearing process (Terra et al 1996). The beetle in this study was exposed to cucumber plants during the rearing period and proximate analysis showed that cucumber contained $95 \%$ water, $3-4 \%$ carbohydrate, $0.7 \%$ protein, $0.12 \%$ fat, $0.4 \%$ fiber and $0.4 \%$ ash (Ekwu et al 2007 ).

In addition, the age of the insect during post-embryonic development had a significant effect on the enzyme activities in the guts. Cellulase activity in the guts of E. chrysomelina was significantly higher $(p<0.05)$ in the adult stage of the insect development as compared to the immature stages of which the $4^{\text {th }}$ instar larvae recorded a significantly higher cellulase activity (Table 1). Cellulase activity in the guts as reported by Pigman and Horton (1970) and Ademolu et al (2013) are for the digestion and utilization of various carbohydrates consumed by the beetle. Activity of a-glucosidase which was responsible for the breakdown of the product of cellulose hydrolysis was observed to be significantly higher in the $4^{\text {th }}$ instar larvae relative to other stages of development and lowest in the adult stage (Table 2). Amylase which is for starch hydrolysis recorded significantly higher activity in the adult stage (Table 3 ). Lipase and proteinase activities were highest in the immature stages relative to the adult stages (Tables 4 and 5 ). The $4^{\text {th }}$ instar larvae recorded higher activities of proteinase and lipase activities relative to the $1^{\text {st }}, 2^{\text {nd }}$ and $3^{\text {rd }}$ instars, this observation agrees with an earlier report by Mandal and Chaudhuri (1981) that proteinase and lipase activities were more significant in the gut of the later instars of a large cricket Schizodactylus monstrosus. As the insects developed from the $1^{\text {st }}$ larval instar to the $4^{\text {th }}$ instar, there were increases in the size of the guts and increases in enzyme activities leading to more food consumption (Ademolu \& Idowu 2011). More enzyme activities were observed in the $4^{\text {th }}$ larval instar and the adult stage which implied more digestion and more consumption of the host 
tissues took place at these stages of development and thus can be regarded as the most voracious and destructive stages. The midgut region of $E$. chrysomelina recorded significantly $(p<0.05)$ higher cellulase $(19.46 \pm 0.3 \mathrm{Abs}$ per $\mathrm{min})$, a-glucosidase (25.65 $\pm 0.1 \mathrm{Abs}$ per $\mathrm{min})$, lipase $(38.24 \pm 0.1 \mathrm{Abs}$ per $\mathrm{min}$ ) and proteinase $(29.70 \pm 1.1 \mathrm{Abs}$ per $\mathrm{min}$ ) activities relative to other gut regions in the study. This corroborates the findings of Ademolu and Idowu (2011) that of the three gut regions in the digestive tract of Zonocerus variegatus, the midgut had the highest enzymatic activity. The midgut has been demonstrated as the major site for digestive enzyme secretion in insects due to its simple structure composed of columnar and regenerative cells (Dow 1981, Terra 1990). The foregut recorded the highest amylase ( $16.60 \pm 0.1 \mathrm{Abs}$ per min) activity; this must have been as a result of enzyme's movement from the midgut to the foregut since digestive enzymes can flow forward as well as backward in the alimentary canal of the insect. An earlier study by Hill and Orchard (2005) revealed significantly higher amylase activity in the foregut of orthopterans despite the actual release of the enzyme from the midgut.

Table 1. Cellulase activity $( \pm S E)$ in the gut regions of Epilachna chrysomelina during post embryonic development (Abs/min)

\begin{tabular}{lccc}
\hline Stages & Foregut & Midgut & Hindgut \\
\hline 1st instar & $2.50 \pm 0.1 \mathrm{~d}$ & $3.50 \pm 0.1 \mathrm{~d}$ & $2.70 \pm 0.1 \mathrm{~d}$ \\
2nd instar & $5.20 \pm 0.1 \mathrm{c}$ & $6.52 \pm 0.2 \mathrm{~d}$ & $4.00 \pm 0.1 \mathrm{~d}$ \\
3rd instar & $7.15 \pm 0.1 \mathrm{c}$ & $13.40 \pm 0.1 \mathrm{c}$ & $11.1 \pm 0.2 \mathrm{c}$ \\
4th instar & $11.32 \pm 0.2 \mathrm{~b}$ & $16.10 \pm 0.1 \mathrm{~b}$ & $14.65 \pm 0.2 \mathrm{~b}$ \\
Adult & $18.67 \pm 0.2 \mathrm{a}$ & $19.46 \pm 0.3 \mathrm{a}$ & $17.50 \pm 0.3 \mathrm{a}$
\end{tabular}

Means in the same column with the same letter are not significantly different ( $p>0.05)$ using Studentised Newman Keuls (SNK) $\mathrm{Abs} / \mathrm{min}=$ Absorbance per minute

Table 2. a-glucose activity ( \pm SE) in the gut regions of Epilachna chrysomelina during post embryonic development (Abs/min)

\begin{tabular}{lccc}
\hline Stages & Foregut & Midgut & Hindgut \\
\hline 1st instar & $15.20 \pm 0.2 \mathrm{~b}$ & $18.45 \pm 0.1 \mathrm{c}$ & $13.24 \pm 0.1 \mathrm{~b}$ \\
2nd instar & $15.75 \pm 0.2 \mathrm{~b}$ & $20.81 \pm 0.3 \mathrm{bc}$ & $14.32 \pm 0.1 \mathrm{~b}$ \\
3rd instar & $19.00 \pm 0.1 \mathrm{a}$ & $23.38 \pm 0.2 \mathrm{~b}$ & $16.20 \pm 0.2 \mathrm{a}$ \\
4th instar & $20.62 \pm 0.2 \mathrm{a}$ & $25.65 \pm 0.1 \mathrm{a}$ & $17.00 \pm 0.1 \mathrm{a}$ \\
Adult & $14.00 \pm 0.1 \mathrm{~b}$ & $16.25 \pm 0.1 \mathrm{~b}$ & $10.45 \pm 0.1 \mathrm{c}$ \\
\hline
\end{tabular}

Means in the same column with the same letter are not significantly different $(p>0.05)$ using Studentised Newman Keuls (SNK) $\mathrm{Abs} / \mathrm{min}=$ Absorbance per minute

Table 3: Amylase activity ( \pm SE) in the gut regions of Epilachna chrysomelina during post embryonic development (Abs/min)

\begin{tabular}{lccc}
\hline Stages & Foregut & Midgut & Hindgut \\
\hline 1st instar & $16.22 \pm 0.1 \mathrm{a}$ & $13.25 \pm 0.2 \mathrm{~b}$ & $9.20 \pm 0.2 \mathrm{c}$ \\
2nd instar & $16.34 \pm 0.1 \mathrm{a}$ & $15.00 \pm 0.3 \mathrm{a}$ & $12.02 \pm 0.1 \mathrm{~b}$ \\
3rd instar & $16.25 \pm 0.2 \mathrm{a}$ & $15.32 \pm 0.2 \mathrm{a}$ & $12.75 \pm 0.1 \mathrm{~b}$ \\
\hline
\end{tabular}


Table 3 continued

\begin{tabular}{lccc}
\hline Stages & Foregut & Midgut & Hindgut \\
\hline 4th instar & $16.60 \pm 0.1 \mathrm{a}$ & $16.25 \pm 0.1 \mathrm{a}$ & $14.30 \pm 0.2 \mathrm{a}$ \\
Adult & $16.62 \pm 0.2 \mathrm{a}$ & $13.25 \pm 0.2 \mathrm{~b}$ & $14.30 \pm 0.1 \mathrm{a}$ \\
\hline
\end{tabular}

Means in the same column with the same letter are not significantly different $(p>0.05)$ using Studentised Newman Keuls (SNK) $\mathrm{Abs} / \mathrm{min}=$ Absorbance per minute

Table 4. Lipase activity $( \pm S E)$ in the gut regions of Epilachna chrysomelina during post embryonic development (Abs/min)

\begin{tabular}{lccc}
\hline Stages & Foregut & Midgut & Hindgut \\
\hline 1st instar & $19.70 \pm 0.1 \mathrm{c}$ & $19.80 \pm 0.2 \mathrm{c}$ & $18.00 \pm 0.2 \mathrm{c}$ \\
2nd instar & $23.00 \pm 0.2 \mathrm{~b}$ & $25.11 \pm 0.2 \mathrm{c}$ & $20.16 \pm 0.2 \mathrm{~b}$ \\
3rd instar & $25.45 \pm 0.1 \mathrm{~b}$ & $32.25 \pm 0.2 \mathrm{~b}$ & $20.28 \pm 0.1 \mathrm{~b}$ \\
4th instar & $35.91 \pm 0.2 \mathrm{a}$ & $38.24 \pm 0.1 \mathrm{a}$ & $22.57 \pm 0.2 \mathrm{a}$ \\
Adult & $13.46 \pm 0.1 \mathrm{~d}$ & $14.10 \pm 0.1 \mathrm{~d}$ & $14.21 \pm 0.1 \mathrm{c}$ \\
\hline
\end{tabular}

Means in the same column with the same letter are not significantly different $(p>0.05)$ using Studentised Newman Keuls (SNK) $\mathrm{Abs} / \mathrm{min}=$ Absorbance per minute

Table 5. Proteinase activity $( \pm S E)$ in the gut regions of Epilachna chrysomelina during post embryonic development (Abs/min)

\begin{tabular}{lccc}
\hline Stages & Foregut & Midgut & Hindgut \\
\hline 1st instar & $12.10 \pm 1.1 \mathrm{a}$ & $15.63 \pm 1.2 \mathrm{c}$ & $10.20 \pm 1.0 \mathrm{a}$ \\
2nd instar & $20.43 \pm 1.0 \mathrm{c}$ & $20.92 \pm 1.1 \mathrm{~b}$ & $12.45 \pm 0.9 \mathrm{a}$ \\
3rd instar & $22.45 \pm 1.2 \mathrm{~b}$ & $26.43 \pm 1.0 \mathrm{a}$ & $15.30 \pm 1.1 \mathrm{a}$ \\
4th instar & $23.62 \pm 1.0 \mathrm{a}$ & $28.70 \pm 1.3 \mathrm{a}$ & $16.00 \pm 1.1 \mathrm{a}$ \\
Adult & $15.40 \pm 1.0 \mathrm{~d}$ & $16.25 \pm 1.1 \mathrm{c}$ & $10.50 \pm 1.1 \mathrm{a}$
\end{tabular}

Means in the same column with the same letter are not significantly different $(p>0.05)$ using Studentised Newman Keuls (SNK) $\mathrm{Abs} / \mathrm{min}=$ Absorbance per minute

In conclusion, the $4^{\text {th }}$ larval instar, as well as the adult stage of development in $E$. chrysomelina contained more enzyme activity relative to other stages indicating that more digestion took place at these stages. This indicates that the beetle is more voracious and destructive at these stages so management measure should be put in place before the stages are attained.

\section{REFERENCES}

Adedire CO, Imevbore EA, Eyide EO \& Ayodele WI. 1999. Aspects of digestive physiology and the complementary roles of the microbial enzymes in the intestinal tract of the giant land snail, Archachatina marginata (Swainson). Journal of Technoscience 3:6-13 
Adedire CO and Balogun RA. 1995. Digestive enzymes and regional localization of proteolytic endopeptidases in alimentary canal of kola nut weevil, Sophrorhinus insperatusn Faust (Coleoptera: Curculionidea). Entomon 20(3):183-189

Ademolu KO and Idowu AB. 2011. Activity of digestive enzymes in Zonocerus variegatus (Orthoptera: Pyrgomorphidae) gut homogenates during postembryonic development. International Journal of Tropical Insect Science 31(12):29-33

Ademolu KO, Fakeye OD, Dedeke GA, Ajayi OA \& Idowu AB. 2013. Digestive enzymes in African giant land snail (Archachatina marginata) during estivation. Archivos de Zootecnia 62(237):73-77

Akinkunmi OY. 2020. Bioecology of Epilachna chrysomelina Fabricius (Coleoptera: Coccinellidae) on five vegetable hosts in a rain forest transition location of Nigeria and control with botanicals (PhD dissertation). Department of Crop Protection, College of Plant Science and Crop Production, Federal University of Agriculture Abeokuta, Nigeria

Chapman R. 1990. The insect: structure and function. The english language book society and hodder and stoughton. Great Britain

Dow JAT. 1981. Counter current flows, water movements and nutrient absorption in the locust midgut. Journal of Insect Physiology 27(9):579-585

Ekwu LG, Utobo EB \& Oyesola CA. 2007. Vegetative and yield response of cucumber (Cucumis sativus L.) to staking and nitrogen fertilizer application. Journal of Applied Sciences 19(4):7509-7519

Hill SR and Orchard I. 2005. Enzymes in the gut during starvation. Journal of Insect Physiology 51(1):1-9

Hossain MS, Khan AB, Haque MA, Mannan MA \& Dask CK. 2009. Effect of different host plants on growth and development of Epilachna beetle. Bangladesh Journal of Agricultural Research 34(3):403-404

Katoh T, Koji S, Ishida TA, Matsubayashi KW, Kahono S, Kobayas N, Furukawa K, Viet BT, Neto JV, Lange CN, Goergen G, Nakano S, Li N, Yu G \& Katakura H. 2014. Phylogeny of Epilachna henosepilachna, and some minor genera of phytophagous ladybird beetles (Coleoptera: Coccinellidae: Coccinellinae: Epilachnini) with an analysis of ancestral biogeography and host-plant utilization. Zoological Science 31(12): 820-830

Mandal S, Roy S \& Chaudhuri DK. 1981. Quantification of protease, amylase, and lipase in the gut of Schizodactylus monstrosus during the postembryonic development stage. Effect of starvation, stress and topical application of juvenile hormone analogue. Acta Physiologica Academiae Scientiarum Hungaricae 58(1):53-64

Murata M, Iwabuchi K \& Mitsuhashi J. 1994. Partial rearing of phytophagous lady beetle, Epilachna vigintioctopunctata (Coleoptera: Coccinellidae). Applied Zoology and Entomology 29(1):116-119

Pigman W and Horton D. 1970. The carbohydrates, chemistry and biochemistry IIA (2nd edn). Academic Press, New York

Pitan OOR and Esan EO. 2013. Intercropping cucumber with amaranth (Amaranthus cruentus L) to suppress population of major pests of cucumber (Cucumis sativus L.). Archives of Phytopathology and Plant Protection 47(9):1112-1119

Pitan OOR and Filani CO. 2013. Assessment of insect spectrum and insect-induced damage at different growth stages of cucumber (Cucumis sativus L.) in a rainforest transition zone of Nigeria. Annals of Tropical Research 35(2):60-68 
Terra WR, Ferreira C, Jordao BP \& Dillon RJ. 1996. Digestive enzymes. In Lebane MJ and Billingsley PF(eds) Biology of the insect mid gut (pp153-193). Chapman and Hall UK

Terra WR. 1990. Evolution of digestive systems of insects. Annual Review of Entomology 25:181-200

Vishav SJ, Hafeez A, Ashutosh S \& Devinder S. 2017. Seasonal abundance of Henosepilachna vigintioctopunctata (Fab.) on Solanum melongena L. and natural occurrence of its two hymenopteran parasitoids. Brazilian Archives of Biology and Technology 60:1-11 